\author{
NBER WORKING PAPER SERIES \\ ON \\ HISTORICAL FACTORS IN LONG RUN GROWTH
}

\title{
MANUFACTURING WHERE AGRICULTURE \\ PREDOMINATES: EVIDENCE FROM \\ THE SOUTH AND MIDWEST IN 1860
}

\author{
Kenneth L. Sokoloff \\ Viken Tchakerian
}

Historical Paper 100

\section{NATIONAL BUREAU OF ECONOMIC RESEARCH \\ 1050 Massachusetts Avenue \\ Cambridge, MA 02138 \\ April 1997}

The authors gratefully acknowledge helpful suggestions from Stanley Engerman, Naomi Lamoreaux, John Majewski, Rebecca Menes, Duncan Thomas, Gavin Wright, and participants in the Von Gremp Workshop in Economic and Entrepreneurial History at UCLA. The research was supported by the National Science Foundation. This paper is part of NBER's research program in the Development of the American Economy. Any opinions expressed are those of the authors and not those of the National Bureau of Economic Research.

(C) 1997 by Kenneth L. Sokoloff and Viken Tchakerian. All rights reserved. Short sections of text, not to exceed two paragraphs, may be quoted without explicit permission provided that full credit, including (C) notice, is given to the source. 
Manufacturing Where Agriculture Predominates:

Evidence from the South and Midwest in 1860

Kenneth L. Sokoloff and Viken Tchakerian

NBER Historical Paper No. 100

April 1997

JEL Nos. N0, N5, O0, Q0

Development of the American Economy

\section{ABSTRACT}

We employ the 1860 Census of Manufactures to study rural antebellum manufacturing in the South and Midwest, and find that manufacturing output per capita was similar across regions in counties specialized in the same agricultural products. The southern deficit in manufactures per capita appears to have been largely attributable to the very low levels of output in counties specialized in cotton production. This implies that it was the South's capabilities for the highly profitable cotton production, not the existence of slavery per se, that was responsible for the region's limited industrial development -- at least in rural areas. The other major finding is that in both the South and the Midwest measured total factor productivity was significantly lower in counties specialized in wheat (the most seasonal of agricultural products as regards labor requirements). This is consistent with suggestions that agricultural districts where the predominant crops were highly seasonal in their requirements for labor were well suited to support manufacturing enterprise during the offpeak periods.

Kenneth L. Sokoloff

Department of Economics

University of California

405 Hilgard Avenue

Los Angeles, CA 90095

and NBER

sokoloff@ucla.edu
Viken Tchakerian

Department of Economics

California State University

18111 Nordoff Street

Northridge, CA 91330

v.tchakerian@csun.edu 
Economic historians have long been concerned with whether and how conditions of local agricultural production had important impacts on the paths of manufacturing development in pre- and early industrial economies. A wide range of effects that agricultural activities could have on the level, type, and organization of manufacturing have been proposed as significant in one context or another, including those working through institutions, demand, or supplies of labor, capital, and raw materials. Scholars of Europe, for example, seeking to understand why early manufacturing was more likely to emerge as a major activity in certain districts rather than others, tend to highlight characteristics like the relationship between the supply of labor in manufacturing and variations in the prevalence of tenancy, the size of landholdings, the number of landless workers, and seasonality in labor requirements across crop. ${ }^{1}$ Economic historians of the United States, drawn to the subject primarily by a concern with regional disparities in the patterns of growth, have in contrast explored a broader set of possible ways through which conditions in the agricultural sector might have affected the course of manufacturing development. ${ }^{2}$

The debate over why the the U.S. South lagged in developing a substantial manufacturing sector, in particular, has focused attention on a variety of mechanisms through which the vitality of manufacturing enterprise may have been hampered by the institution of slavery or by the composition of the agricultural sector in the region. Prominent explanations for how slavery retarded industrial development include: that slaves were absolutely or relatively less productive in manufacturing than a free labor force; that the unequal distribution of income associated with slavery would not sustain scale economies in the mass production of consumer goods and the evolution of product markets; and that slave agriculture had an unfavorable impact on the quality of entrepreneurs who chose to pursue manufacturing. Some scholars place less emphasis on slavery, however, and suggest that 
other features of southern agriculture may bear at least some responsibility for the region's limited industrial development. They contend that the South was at a comparative disadvantage in early manufacturing either because of the relatively higher productivity of women and children in the agricultural commodities like cotton and tobacco produced there (which raised the cost of the groups of workers manufacturing was intensive in), or because the region's soil types and climate were very favorable to the production of cotton -- a commodity highly valued on world markets over the nineteenth century. ${ }^{3}$ Finally, although most of the research into the linkages between conditions in the agricultural sector and early manufacturing in the United States has been concerned with the sources of southern backwardness, recent work comparing the U.S. and England has indicated that geographic districts with substantial variability over time in agricultural labor requirements, such as those specialized in wheat production, would tend to be characterized by less productive manufacturing enterprises than elsewhere because of a trade-off between technical efficiency and flexibility in the timing and place of work. ${ }^{4}$

Most of the systematic work by American economic historians on the relationships between the type of agricultural development and industry has been conducted on a highly aggregated level, implicitly treating regions, or other large geographic units, as rather homogenous. Although there is general acknowledgement that circumstances varied within regions, as seen for the South in the contrast between the border states and the cotton belt, work on manufacturing productivity, profitability, and output levels have typically lumped such sub-regions together -- comparing, for example, southern performance to northern or midwestern performance. ${ }^{5}$ Much has been learned from these studies, but one can go further in investigating the relationships between conditions in agriculture and manufacturing 
development by examining variation within regions. In this paper we report on our effort to do so by employing the Bateman-Weiss sample of establishments drawn from the 1860 Census of Manufactures to study manufacturing in areas that were predominantly agricultural. ${ }^{6}$ Sub-samples of establishments located in the rural areas of the South and the East North Central (the part of the North that was predominantly agricultural) were extracted from the general sample, and each observation was then linked with information about the composition of agricultural output in the local county.

These data allow us to explore relationships between agricultural conditions and early manufacturing development in the U.S., as well as to subject some of the hypotheses advanced to explain southern backwardness in manufacturing to new tests of consistency with the evidence. More specifically, we examine how rural manufacturing in the South compared to that in the North, after controlling for the composition of agricultural output at the county level. The logic of this approach is that it can at least partially distinguish between the effects on manufacturing development of the institution of slavery, and of the kinds of agricultural products that are locally produced (which may reflect aspects of the factor endowment like soil type or climate).

Our analysis indicates that, as Tchakerian (1994) found in previous work, manufacturing enterprises in the South were generally comparable with those in the East North Central in terms of productivity. What is new, however, is the result that manufacturing output per capita appears to have been quite similar across regions in counties specialized in agricultural products produced in both the South and the East North Central -- like wheat, corn, and animal products. The southern deficit in manufactures per capita in rural areas seems, therefore, largely attributable to the low levels of manufacturing output in counties 
specialized in cotton production. The implication is that it was the South's capabilities for highly profitable cotton production, not the existence of slavery per se, that was responsible for the region's relatively low level of manufacturing activity -- at least in rural areas. The other major finding is that in both the South and the East North Central measured total factor productivity was significantly lower in counties specialized in wheat (the most seasonal of agricultural products as regards labor requirements). This is consistent with suggestions that agricultural districts where the predominant crops were highly seasonal in their requirements for labor were well suited to support manufacturing enterprise during the offpeak periods. Manufacturing establishments in such areas were less likely to be in production full-time year round, and were as a result generally less efficient in a technical sense, but they survived in competition through operating during intervals when the opportunity cost of labor was low.

\section{II}

With early industrial development in the U.S. concentrated in the Northeast, the South and the East North Central remained predominantly agricultural throughout the antebellum period. Though manufacturing was at best a modest activity in both regions, the former devoted a much smaller share of its resources to that sector than did the latter. ${ }^{7}$ This contrast is immediately evident from the regional figures on manufacturing value added per capita presented in Table 1. Although the manufacturing sector grew extremely rapidly in the South over the twenty years preceding the Civil War, the region still lagged far behind its northern counterpart on the eve of that conflict. ${ }^{8}$ Manufacturing value added in the South (\$19.61) was not quite half that in the East North Central (\$40.66) on a per capita 
TABLE 1

PER-CAPITA MANUFACTURING VALUE ADDED: URBAN-RURAL COMPARISON ACROSS INDUSTRY GROUPS, 1860

\begin{tabular}{|l|l||l|l||l|l||l||l|l||l|l|}
\hline & \multicolumn{5}{|c|}{ SOUTH } & \multicolumn{4}{|c|}{ EAST NORTH CENTRAL } \\
\cline { 2 - 10 } & All & Urban & $\%$ & Rural & $\%$ & All & Urban & $\%$ & Rural & $\%$ \\
\hline $\begin{array}{l}\text { ALL } \\
\text { MANUFACTURING }\end{array}$ & 19.61 & 73.69 & 84.6 & 13.41 & 15.4 & 40.66 & 101.86 & 78.4 & 28.03 & 21.6 \\
\hline Resource Processing & 10.10 & 33.01 & 81.5 & 7.49 & 18.5 & 20.28 & 36.91 & 68.7 & 16.84 & 31.3 \\
\hline $\begin{array}{l}\text { Without Resource } \\
\text { Processing }\end{array}$ & 9.51 & 40.68 & 87.3 & 5.92 & 12.7 & 20.38 & 64.95 & 85.3 & 11.19 & 14.7 \\
\hline $\begin{array}{l}\text { Leather \& Leather } \\
\text { Goods }\end{array}$ & 1.29 & 3.97 & 80.2 & 0.98 & 19.8 & 2.38 & 5.23 & 75.4 & 1.71 & 24.6 \\
\hline Textiles \& Woollens & 1.20 & 2.81 & 73.4 & 1.02 & 26.6 & 0.44 & 0.92 & 73.0 & 0.34 & 27.0 \\
\hline $\begin{array}{l}\text { Household \& } \\
\text { Personal Goods }\end{array}$ & 1.22 & 6.15 & 90.3 & 0.66 & 9.7 & 3.91 & 16.60 & 92.8 & 1.29 & 7.2 \\
\hline $\begin{array}{l}\text { Population distribution } \\
\text { (\%) }\end{array}$ & 100 & ---- & 10.3 & --- & 89.7 & 100 & --- & 17.1 & --- & 82.9 \\
\hline
\end{tabular}

Notes: The South includes Alabama, Georgia, Kentucky, Louisiana, Mississippi, North Carolina, South Carolina, Tennessee, and Virginia. The East North Central includes Illinois, Indiana, Michigan, Ohio, and Wisconsin.

Urban counties in the South contain a city of 5000 inhabitants or more, while in the East North Central region only counties with a city of 7000 or more inhabitants were classified as urban.

Industry groups are as follows:

Resource processing: flour; lumber; liquor; meatpacking; tobacco; and tar/turpentine.

Leather and leather goods: leather; boots and shoes; and saddles.

Textiles and woollens: cotton; woollen; and mixed cotton-woollen textiles.

Household and personal goods: carriages and wagons; furniture; clothing; hats and millinery; and soaps.

Sources: Eight Census of the United States, Manufactures (1865), and U.S. Bureau of the Census, Historical Statistics (1975) Series A123-180. 
basis. The large imbalance extended across both urban and rural counties, but since southern manufacturing was relatively more concentrated in cities (where at $\$ 73.69$ per capita value added was nearly six times that in rural counties, as opposed to less than four times that in the East North Central), the proportional gap between the regions was even greater in rural areas. The 10.3 percent of the southern population residing in urban counties managed to produce 84.6 percent of the regions's manufacturing output, as compared to the 78.4 percent of East North Central's manufacturing being accounted for by the 17.1 percent of its population in urban areas. The only major industry category in which southerners managed to surpass midwesterners was cotton and woolen textiles, which was a minor activity in both regions. Despite the salient difference between regions in the relative commitment of resources to manufacturing, however, the South and East North Central were alike in having roughly half of their industrial output accounted for by resource-processing industries: flour milling, lumber, liquors, meatpacking, tobacco products, and tar/turpentine.

Although the South certainly trailed the East North Central in manufacturing output per capita, regional comparisons of other measures of industrial performance, as seen in Table 2 , reveal little if any indication of southern backwardness. For example, there is no consistent advantage in average firm size for either region after one controls for industry. It is noteworthy, perhaps, that within urban counties southern firms were larger on average in every category, but this feature serves to highlight the equally striking finding that the variation in the size of firms between urban and rural areas was rather trivial in the East North Central as compared to the record in the South. This latter feature may reflect the greater degree of integration among product markets for manufactures in the East North 
TABLE 2

AVERAGE NUMBER OF EMPLOYEES PER FIRM AND TOTAL FACTOR PRODUCTIVITY BY REGION AND URBANIZATION, FOR SELECTED INDUSTRY CATEGORIES, 1860

\begin{tabular}{|c|c|c|c|c|c|c|}
\hline \multirow[t]{2}{*}{. } & \multicolumn{3}{|c|}{ SOUTH } & \multicolumn{3}{|c|}{ EAST NORTH CENTRAL } \\
\hline & All & Urban & Rural & All & Urban & Rural \\
\hline $\begin{array}{l}\text { Resource Processing } \\
\text { average number of employees } \\
\text { total factor productivity }\end{array}$ & $\begin{array}{l}3.2(577) \\
69.0(545)\end{array}$ & $\begin{array}{l}14.7(20) \\
94.5(18)\end{array}$ & $\begin{array}{l}2.8(557) \\
67.9(527)\end{array}$ & $\begin{array}{l}4.7(335) \\
78.3(312)\end{array}$ & $\begin{array}{l}5.9(26) \\
84.9(24)\end{array}$ & $\begin{array}{l}4.6(309) \\
78.0(288)\end{array}$ \\
\hline $\begin{array}{l}\text { Iron \& Metal Products } \\
\text { average number of employees } \\
\text { total factor productivity }\end{array}$ & $\begin{array}{l}11.6(63) \\
80.3(59)\end{array}$ & $\begin{array}{l}23.6(10) \\
76.1(8)\end{array}$ & $\begin{array}{l}10.2(53) \\
79.6(51)\end{array}$ & $\begin{array}{l}5.0(74) \\
63.8(67)\end{array}$ & $\begin{array}{l}9.9(9) \\
73.3(7)\end{array}$ & $\begin{array}{l}4.5(65) \\
65.3(60)\end{array}$ \\
\hline $\begin{array}{l}\text { Leather \& Leather Goods } \\
\text { average number of employees } \\
\text { total factor productivity }\end{array}$ & $\begin{array}{l}3.0(228) \\
61.5(222)\end{array}$ & $\begin{array}{l}4.1(17) \\
82.8(17)\end{array}$ & $\begin{array}{l}2.9(211) \\
58.7(205)\end{array}$ & $\begin{array}{l}3.1(145) \\
70.0(139)\end{array}$ & $\begin{array}{l}3.8(28) \\
80.9(27)\end{array}$ & $\begin{array}{l}2.9(117) \\
68.2(112)\end{array}$ \\
\hline $\begin{array}{l}\text { Textiles \& Woollens } \\
\text { average number of employees } \\
\text { total factor productivity }\end{array}$ & $\begin{array}{l}49.2(22) \\
85.2(21)\end{array}$ & $\begin{array}{l}135.0(2) \\
57.3(1)\end{array}$ & $\begin{array}{l}44.9(20) \\
84.0(20)\end{array}$ & $\begin{array}{l}7.2(10) \\
62.3(10)\end{array}$ & $\begin{array}{l}5.5(2) \\
88.8(2)\end{array}$ & $\begin{array}{l}7.6(8) \\
63.6(8)\end{array}$ \\
\hline $\begin{array}{l}\text { Household \& Personal Goods } \\
\text { average number of employees } \\
\text { total factor productivity }\end{array}$ & $\begin{array}{l}5.6(113) \\
82.9(107)\end{array}$ & $\begin{array}{l}12.0(18) \\
87.0(15)\end{array}$ & $\begin{array}{l}4.8(95) \\
80.8(92)\end{array}$ & $\begin{array}{l}5.6(154) \\
86.0(138)\end{array}$ & $\begin{array}{l}7.6(46) \\
138.2(39)\end{array}$ & $\begin{array}{l}4.8(108) \\
77.9(99)\end{array}$ \\
\hline
\end{tabular}

Notes and Sources: The industry groups are the same as Table 1 with two exceptions. The Resource Processing group is here comprised of flour, lumber, and the distilling of liquor while the composition of the Iron \& Metal products includes pig and bar iron, tin-and-copperware, and agricultural implements.

The firm size estimates were calculated from the Bateman-Weiss sample of southern and midwestern manufacturing firms as unweighted averages.

Total Factor Productivity was computed according to the following formulation; TFP = $\mathrm{VA} /\left(\mathrm{L}^{0.7} \mathrm{X} \mathrm{K}^{0.3}\right)$, where VA is value added (that is value of output minus value of raw materials); $\mathrm{L}$ is total equivalent worker, calculated as $\mathrm{L}=\mathrm{M}+0.5 \mathrm{~F}+\mathrm{E}$, where $\mathrm{M}$ is number of male labor, $\mathrm{F}$ is number of female labor, and $E$ is the entrepreneurial input of one male worker per firm; and $K$ is the value of the capital inputs. See Tchakerian (1994) for further discussions.

The TFP estimates were computed over the firm observations of the sample of the respective industries after excluding those firms located in the top 2 and bottom 5 percent of the distribution by TFP. 


\section{Table 2 , continued}

The TFP estimates were weighted to take into account the distribution of firms across states. The three categories, "all", "urban", and "rural" were weighted by their respective distribution of firms across states. The weights can be characterized as: TFP $=\sum(\operatorname{tfp})_{\mathrm{ij}}(w)_{j}$ where $(\mathrm{tfp})_{\mathrm{ij}}$ is the total factor productivity of the jth state in the ith industry group, and the $(\mathrm{w})_{\mathrm{j}}$ is the ratio of the number of firms in state $j$ to the total number of firms in that specific region.

Sources: The table estimates were calculated from the Bateman-Weiss sample of southern and midwestern manufacturing firms. The South is represented by Alabama, Kentucky, Mississippi, North and South Carolina, Tennessee, and Virginia. The East North Central is represented by Illinois, Indiana, Michigan, Ohio, and Wisconsin. 
Central, consistent with the impression given by the greater share of the region's manufactures produced in rural counties.

Another common and relevant basis for evaluating the vitality of manufacturing enterprise is total factor productivity. Although some scholars have suggested that southern manufacturers were somewhat lacking in entrepreneurship, the estimates in Table 2 of total factor productivity, for selected industries and by region, indicate that the situation on the eve of the Civil War was more complex. The figures have to be interpreted carefully, because of the small number of observations in some of the cells and differences across industries, but in general, southern manufacturers performed as well as their counterparts in the East North Central, both overall as well as in urban and rural counties considered separately. The regional patterns were also similar in that, as Tchakerian (1994) has shown, manufacturing in both regions was characterized by substantial economies of scale, especially in rural counties. ${ }^{9}$

Such aggregate regional figures do not, by themselves, distinguish empirically between the general interpretations that have been offered as to why the southern manufacturing sector was so small on the eve of the Civil War. Proponents of the view that the existence of slavery retarded the expansion of industrial output can base their case on the observation that the manufacturing output per capita in the South fell below that of the other predominantly agricultural region in the U.S. -- the East North Central. Those who do not believe that the institution of slavery was directly responsible, typically hold that the region committed a smaller share of its resources to industry because of a strong comparative advantage in cotton. They point out that the manufacturing enterprise that did exist in the South was comparable in performance to that of the East North Central. In this view, the 
manufacturing sector in the South was rather small, because the highest-value use of resources in much of the region was in the production of cotton.

Given that each of the two general interpretations is consistent with the aggregate data, it seems useful to subject them to a test based on more disaggregated information. The most straightforward approach is to examine whether the southern deficiency in manufacturing extended uniformly across the entire region, or whether it was concentrated in districts that were relatively specialized in cotton. This analytical framework provides the basis for the estimates of manufacturing value added per capita presented in the two panels of Table 3 for sets of rural counties of the South and the East North Central categorized by agricultural specialization. The counties in each region were classified as to specialization of agriculture by whether they placed in that region's top quartile of counties by the proportion of agricultural output accounted for by the respective product. ${ }^{10}$ Counties that did not meet the criterion for specialization in any of the major products considered were classified as nonspecialized. After the various counties in the South and East North Central were so classified, the variation in manufacturing activity across counties was examined by using the random sample of manufacturing firms collected by Bateman and Weiss, where individual firm observations were linked to agricultural specialization by the county in which they were located, and weighted by state-specific weights to compute the estimates for categories of counties.

It is immediately apparent that rural manufacturing in the South, whether overall or by industry, was far from proportional to population across districts. In the South, rural manufacturing value added per capita was much higher in counties specialized in wheat, tobacco, and animal products than it was in counties specialized in corn or cotton, or in 
TABLE 3

NONURBAN MANUFACTURING OUTPUT PER-CAPITA ACROSS COUNTIES BY AGRICULTURAL SPECIALIZATION, 1860

(In Current \$)

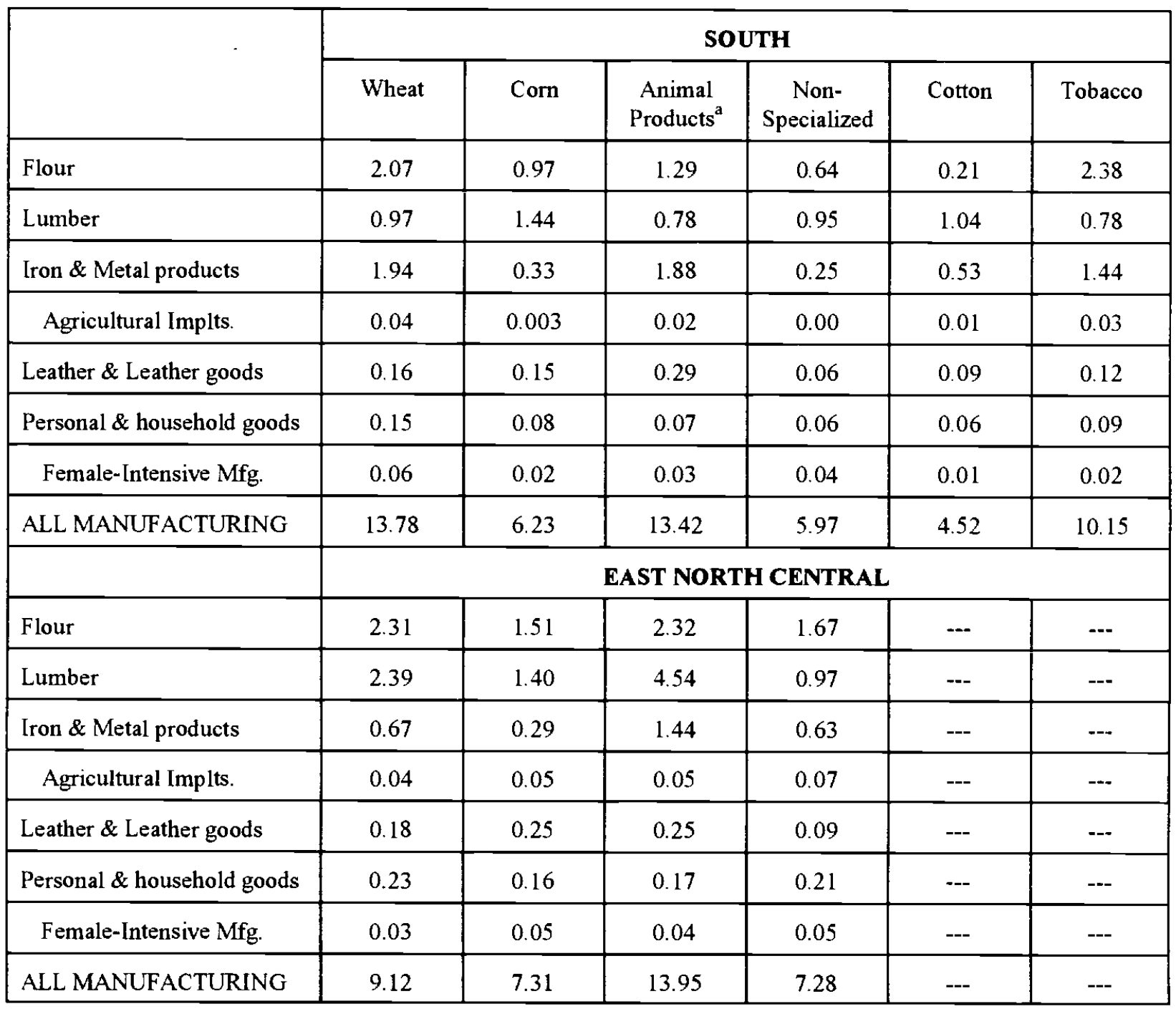

${ }^{a}$ Butchering and butter.

Notes: We define a county as agriculturally specialized if it belongs to the top quartile of the distribution of the ratio $v_{i j} / V_{j}$, where $v_{i j}$ is the value of ith agricultural product in county $j$ and $V_{j}$ is "total" value of agricultural product in county $j$. The "total" value does not include all of the agricultural products mentioned in the Agriculture Census because we do not have all the relevant prices to convert the physical quantities into dollar values. Fortunately we do have price information for the major crops and products to create a composite "basket" that will be representative of the total value of the agricultural products of a county. The composite basket is the sum of the values of wheat, corn, rice, tobacco, cotton, wool, butter, and slaughtered animals. 


\section{Table 3 continued}

The estimates were weighted such that the figures take into account the true distribution of firms across the states. Thus, an individual weight can be represented as $\mathrm{N}_{S} / \mathrm{N}_{T}$, where $\mathrm{N}_{\mathrm{S}}$ is the number of firms in the Bateman-Weiss sample for the group of counties that represent some specific agricultural specialization, and $\mathrm{N}_{\mathrm{T}}$ is the total number of firms obtained from the published Census of Manufacturing in the South for that same specific agricultural specialization (or in the East North Central, as the case may be.)

Sources: The classification of counties in terms of their agricultural specialization was constructed from the published agricultural census, Eight Census of the United States, Agriculture (1865). The prices of the agricultural crops or products were obtained form Cole, Wholesale Commodity Prices (1938) and the average of the years 1859 and 1860 was used. The above data set was then matched with that of the Bateman-Weiss sample of manufacturing firms and the estimates presented in the tables are based on this matched data set. The population figures were calculated form Eight Census of the United States, Population (1865). 
counties classified as nonspecialized. This may not be surprising, given the traditional recognition that Virginia, Kentucky, North Carolina, and Tennessee, the location of most of the former counties, were among the leading industrial states of the South, but what is important for our purposes is how well such counties in the South compared with their counterparts in the East North Central. Wheat-specialized counties in the former region surpassed those of the latter in total manufacturing value added per capita by roughly 50 percent. Similarly, southern counties specialized in animal products produced nearly the same (4 percent less) amount of manufactures per capita as did such counties in the East North Central, while the regional gap was a bit larger (about 15 percent) among counties specialized in corn. There is no clear standard of comparison for southern counties specialized in tobacco, but they also had substantial manufacturing activity, with a level of total value per capita that exceeded that of all classes of rural counties in the East North Central except those specialized in animal products. In a regional comparison of counties classified as nonspecialized, which produced fewer manufactures per capita in both regions, the southern figure was about 20 percent lower than that of the East North Central.

The part of the South in which there was a large shortfall in industrial output relative to population were counties specialized in cotton. In such areas, the level of manufacturing value added per capita was only a third of that reached in counties specialized in either wheat or animal products, and lower than in any other class of counties in either of the two regions. ${ }^{11}$ The implication is that there was rather little to distinguish the South from the North on a per capita basis, except for the very low levels of output in counties specialized in cotton, and for the substantial fractions of the southern population residing there. ${ }^{12}$ Although the bulk of manufacturing output was, in both the South and the East North 
Central, produced in urban (not rural) counties, the regional difference between urban populations in manufacturing value added per capita accounts for less than fifteen percent of the overall regional difference. ${ }^{13}$ This finding may not in itself justify a rejection of the traditional view that a region relying heavily on slave labor could not support as substantial a manufacturing sector as one based on free labor, but it would seem to warrant a rethinking of the sources of and mechanisms behind the lower levels of manufacturing output in the South.

An obvious question that emerges about the interpretation of the low levels of manufacturing activity in counties specialized in cotton is whether the pattern was due to the well known concentration of slaves in those areas, or to some other characteristic of the specific geographic sites or of cotton production. It could be argued, for example, that the evidence presented in Table 3 alone is not inconsistent with the view that slavery was detrimental to the development of manufacturing. In order to distinguish between competing hypotheses, we estimated regressions (reported in Table 4) for the South of manufacturing value added per capita at the county level over a set of dummy variables for crop specialization and access to low-cost transportation, as well as a variable for the proportion of the population that was enslaved. The qualitative results of these regressions, which were run on aggregate county-level information, are very similar to those of the estimated means reported in Table 3, which were built up from the Bateman-Weiss sample of firm data. Counties specialized in cotton again seem to have had much lower manufacturing output per capita than other areas of the South, with nonspecialized counties or those specialized in corn also falling significantly short of the level obtained in wheatspecialized counties. It is striking that these findings hold even after controlling for the 
TABLE 4

CROSS-SECTIONAL REGRESSION OF PER-CAPITA MANUFACTURING VALUE ADDED ON AGRICULTURAL SPECIALIZATION AND SLAVERY: NON-URBAN SOUTH, 1860

\begin{tabular}{|l|c|c|c|}
\hline & \multicolumn{3}{|c|}{ Dependent Variable: Per-Capita Manufacturing } \\
\hline & $\begin{array}{c}8.886 \\
(10.08)^{* * *}\end{array}$ & $\begin{array}{c}7.910 \\
(9.40)^{* * *}\end{array}$ & $\begin{array}{c}7.314 \\
(7.61)^{* * *}\end{array}$ \\
\hline Intercept & $\begin{array}{c}-3.578 \\
(-3.54)^{* * *}\end{array}$ & $\begin{array}{c}-2.957 \\
(-3.09)^{* * *}\end{array}$ & $\begin{array}{c}-3.362 \\
(-3.34)^{* * *}\end{array}$ \\
\hline Cotton & $\begin{array}{c}-2.313 \\
(-2.62)^{* *}\end{array}$ & $\begin{array}{c}-2.128 \\
(-2.55)^{* *}\end{array}$ & $\begin{array}{c}-1.913 \\
(-2.25)^{*}\end{array}$ \\
\hline Tobacco & $\begin{array}{c}-0.376 \\
(-0.40)\end{array}$ & $\begin{array}{c}-0.747 \\
(-0.85)\end{array}$ & $\begin{array}{c}-0.841 \\
(-0.95)\end{array}$ \\
\hline Animal products & -2.215 & -1.738 & -1.510 \\
& $(-2.49)^{* *}$ & $(-2.06)^{*}$ & $(-1.75)$ \\
\hline Non-Specialized & -2.983 & -2.558 & -2.557 \\
& $(-2.53)^{* *}$ & $(-2.29)^{*}$ & $(-2.29)^{*}$ \\
\hline Transportation & -- & $\begin{array}{c}9.592 \\
(8.72)^{* * *}\end{array}$ & $\begin{array}{c}9.466 \\
(8.57)^{* * *}\end{array}$ \\
\hline \% Slave & --- & -- & 2.012 \\
\hline$R^{2}$ & 6.03 & 0.13 & 0.14 \\
\hline$N$ & & 640 & 640 \\
\hline
\end{tabular}

* = Significant at the 5 percent level.

** = Significant at the 1 percent level.

$* * *=$ Significant at the .05 percent level.

Notes: The dummy transportation variable represents counties that have both a town that was mentioned in the Population Census, and a railroad or a navigable waterway passing though or immediately adjacent to its borders. The information on the railroads and navigable waterways was obtained from Meyer et al, History of Transportation (1917). The variables representing agricultural products are also dummy variables representing whether or not a firm belongs to an agriculturally specialized county as described in Table 3. Figures in parentheses are t-statistics. The intercept represents counties that were specialized in wheat.

Sources: Eight Census of the United States, Manufactures (1865), Eight Census of the United States, Agriculture (1865), Eight Census of the United States, Population (1865). 
proportion of the population in the county that were slaves, and that the coefficient on this latter variable is positive (albeit not statistically significant). ${ }^{14}$ This evidence suggests that the substantial shortfall in manufacturing output in cotton-specialized districts should be attributed to some other feature of those areas rather than to the presence or numbers of resident slaves.

Although the basis for the association between manufacturing activity and local agricultural specialization may not be entirely clear, it is interesting that the variation evident in Table 3 is even more systematic at the industry level -- especially in the South. Most prominent is the clustering of resource-processing industries in counties which were relatively specialized in the production of the raw materials they were intensive in. So, for example, flour milling (the figures for which also contain corn milling) was concentrated in wheatgrowing areas in both regions, and very limited in counties geared toward cotton production. Other potential instances of this pattern in the South were the disproportionate production of leather manufactures in counties specialized in animal products, as well as the relatively heavy concentration of lumber production in corn-growing areas. Focusing instead on the contrasts between counties with different types of agricultural specialization, what stands out first is that counties specialized in wheat had disproportionate shares of all manufactured products other than lumber and perhaps leather goods; counties specialized in cotton registered less than proportionate amounts of manufacturing production in all industries, especially in those intensive in female workers. This latter result, together with the similar shortfall of female-intensive manufactures in counties specialized in tobacco, is consistent with the hypothesis of Goldin and Sokoloff (1982 and 1984) that manufacturing industries that were relatively intensive in women and children, like textiles and boots and shoes, were 
less likely to be located in areas with substantial cultivation of cotton, tobacco, and other crops in which the relative productivity of such workers was high.

When one turns to the East North Central, there is some evidence of a relationship between manufacturing output and local agriculture at the industry level, with flour milling disproportionately concentrated in wheat-growing counties, lumber production in counties specialized in animal products or wheat, and leather goods in counties focused on animal products. These cases do not stand out quite so starkly as in the South, however, and the dominant impression one is left with is that the distribution of rural manufacturing corresponded more closely with the distribution of population across the East North Central than in the South.

More insight into the variation in manufacturing activity with local agriculture is provided by the mean values of the shares of total county agricultural product composed of particular crops or products reported in Table 5 for sets of counties classified by type of agricultural specialization and region. The greater similarity apparent across counties in the East North Central in agricultural composition may help explain why manufacturing value added per capita varied less across counties by type of specialization in that region than in the South. There is no midwestern analogue to the southern counties specialized in cotton, where close to 90 percent of agricultural output was composed of a single product. When one considers the extreme degree of agricultural specialization exhibited in this set of counties in conjunction with their low levels of manufacturing output, one is drawn to the conclusion that the very modest amount of manufacturing stemmed basically from resources in such areas being devoted almost exclusively to their comparative advantage -- the production of cotton. ${ }^{15}$ This comparative advantage in cotton could not have been entirely independent 
TABLE 5

MEAN CROP SHARES FOR COUNTIES, BY TYPE OF AGRICULTURAL SPECIALIZATION, 1860

\begin{tabular}{|c|c|c|c|c|c|c|}
\hline & \multicolumn{6}{|c|}{ SOUTH } \\
\hline & \multicolumn{6}{|c|}{ Counties grouped by agricultural product specialization } \\
\hline & Wheat & Corn & $\begin{array}{l}\text { Animal } \\
\text { Products }\end{array}$ & $\begin{array}{c}\text { Non- } \\
\text { Specialized }\end{array}$ & Cotton & Tobacco \\
\hline Wheat & .276 & .131 & .185 & .045 & .006 & .170 \\
\hline Corn & .429 & .654 & .463 & .223 & .068 & .433 \\
\hline $\begin{array}{l}\text { Animal } \\
\text { Products }\end{array}$ & .188 & .176 & .263 & .115 & .033 & .170 \\
\hline Cotton & .021 & .003 & .045 & .563 & .891 & .028 \\
\hline \multirow[t]{2}{*}{ Tobacco } & .074 & .026 & .026 & .001 & .000 & .192 \\
\hline & \multicolumn{6}{|c|}{ EAST NORTH CENTRAL } \\
\hline Wheat & .526 & .148 & .298 & .249 & --- & --. \\
\hline Corn & .255 & .714 & .301 & .546 & --- & --- \\
\hline $\begin{array}{l}\text { Animal } \\
\text { Products }\end{array}$ & .198 & .128 & .363 & .171 & --. & --- \\
\hline
\end{tabular}

Notes and Sources: The figures reported in these tables are the mean agricultural products of the share of output for the categories of counties explained in Table 3. The figures can be read vertically down columns to see the mean crop-share of various agricultural outputs. For example, in wheat specialized counties in the South, corn, on average, accounted for $42.9 \%$ of total value, cotton, $2.1 \%$ of total value, tobacco, $7.4 \%$ of total value, and, animal products, $18.8 \%$ of total value. 
of the institution of slavery, but it must have been based primarily on the soil types and climate which were highly favorable for the cultivation of cotton and characteristic of certain areas of the South. ${ }^{16}$ Not only did the so-called 'cotton belt' continue its specialization at cotton long after slavery was abolished, but the South maintained an international reputation for being exceptionally well endowed for cotton production. ${ }^{17}$

The idea that districts suitable for cotton production committed extraordinary shares of their resources to that activity, and correspondingly little to manufacturing, receives further support from the estimates in Table 5. The counties classified as nonspecialized in the South did not have sufficiently high cotton shares to place them in the top quartile, even though they did average over 56 percent. Like the counties specialized in cotton, however, they had low manufacturing output per capita, compared to the other classes of rural counties in the South as well as to nonspecialized counties in the East North Central. Another implication of the crop share estimates is that southern counties which were relatively specialized in wheat had lower shares of product in wheat than did their counterparts in the East North Central. This presumably reflects the less attractive environment, including soils and climate, in the South for wheat production. It is all the more impressive, therefore, that the same patterns of manufacturing activity were evident, as we will see, in these counties as in the wheat-specialized counties of the Midwest.

Another way of gauging the effects of local agricultural conditions on early manufacturing is to examine the variation in productivity across districts by type of product specialization. Accordingly, in Table 6 we present estimates of how the total factor productivity of various manufacturing industries and of manufacturing overall varied with the composition of local agriculture in both the South and the East North Central, as compared 
TABLE 6

INDEX OF MANUFACTURING PRODUCTIVITY BY INDUSTRY AND AGRICULTURAL SPECIALIZATION, 1860

\begin{tabular}{|c|c|c|c|c|c|}
\hline \multirow[t]{3}{*}{ - } & \multicolumn{5}{|c|}{ SOUTH } \\
\hline & \multicolumn{5}{|c|}{ Corn $=100$} \\
\hline & Wheat & $\begin{array}{l}\text { Animal } \\
\text { Products }\end{array}$ & $\begin{array}{c}\text { Non- } \\
\text { Specialized }\end{array}$ & Cotton & Tobacco \\
\hline Flour & $84(67,34)$ & $108(38,34)$ & $94(32,34)$ & $78(62,34)$ & $113(44,34)$ \\
\hline Lumber & $76(41,42)$ & $66(40,42)$ & $72(53,42)$ & $77(104,42)$ & $100(44,42)$ \\
\hline Leather \& Leather goods & $94(42,30)$ & $109(37,30)$ & $101(19,30)$ & $119(91,30)$ & $112(32,30)$ \\
\hline $\begin{array}{l}\text { Personal \& household } \\
\text { goods }\end{array}$ & $58(28,12)$ & $82(13,12)$ & $74(18,12)$ & $92(58,12)$ & $64(20,12)$ \\
\hline \multirow[t]{2}{*}{$\begin{array}{l}\text { ALL } \\
\text { MANUFACTURING }\end{array}$} & $89(271,175)$ & $100(202,175)$ & $78(179,175)$ & $92(491,175)$ & $90(230,175)$ \\
\hline & \multicolumn{5}{|c|}{ EAST NORTH CENTRAL } \\
\hline Flour & $69(32,19)$ & $80(22,19)$ & $97(23,19)$ & --- & --- \\
\hline Lumber & $77(69,27)$ & $64(44,27)$ & $77(53,27)$ & $-\cdots$ & -- \\
\hline Leather \& Leather goods & $93(37,32)$ & $92(21,32)$ & $81(25,32)$ & -- & --- \\
\hline $\begin{array}{l}\text { Personal \& household } \\
\text { goods }\end{array}$ & $87(36,23)$ & $91(18,23)$ & $95(34,23)$ & $\cdots$ & $\cdots$ \\
\hline $\begin{array}{l}\text { ALL } \\
\text { MANUFACTURING }\end{array}$ & $91(265,156)$ & $79(176,156)$ & $103(213,156)$ & $\cdots$ & --- \\
\hline
\end{tabular}

Notes and Sources: The first figure in the parentheses represents the number of observations of firms located in the categories of counties explained in Table 3 . The second figure represents the number of observations of firms located in corn specialized counties. See Table 3. 
to an index of 100 for productivity in districts specialized in corn. The figures are strongly suggestive of systematic variation in total factor productivity with local agricultural specialization. In the South, manufacturing productivity was markedly lower in counties that were either specialized in wheat or nonspecialized. ${ }^{18}$ Productivity appears to have been highest in counties specialized in corn, or in animal products. The pattern was somewhat different in the East North Central region. Although manufacturing firms in wheatspecialized counties again had lower productivity than their counterparts in corn-specialized counties, the relative productivity of manufacturing in counties specialized in animal products and in counties that were non-specialized contrasted sharply with that in the South. In the East North Central, firms in the former were much less productive than elsewhere, while those in nonspecialized counties were more productive (marginally so relative to those in corn-specialized counties) -- just the opposite of what was the case in the South. One might question whether these results for all manufacturing are simply artifacts due to small sample sizes, but confidence in the qualitative patterns of relatively low productivity of manufacturing in wheat-specialized counties as well as of the relatively high productivity of manufacturing in areas focused on corn is bolstered by their robustness across individual industries and across regions. This finding is interesting in that it is consistent with the argument of Sokoloff and Dollar (1997) that seasonality in agricultural labor requirements, which was especially marked in wheat production, encouraged the use of a less technically efficient organization of manufacturing in early industrial economies like England and the United States.

These qualitative results are subjected to both a multivariate examination and the more conventional assessment of statistical significance in Table 7. Four regressions with the log 
TABLE 7

CROSS-SECTIONAL REGRESSION OF PRODUCTIVITY ON AGRICULTURAL SPECIALIZATION: SOUTH AND EAST NORTH CENTRAL, 1860

\begin{tabular}{|c|c|c|c|c|}
\hline \multicolumn{5}{|c|}{ Dependent Variable: Log (Total Factor Productivity) } \\
\hline & South & $\begin{array}{l}\text { South (Non- } \\
\text { Urban) }\end{array}$ & ENC & $\begin{array}{l}\text { ENC (Non- } \\
\text { Urban) }\end{array}$ \\
\hline Intercept & $\begin{array}{l}4.083 \\
(122.10)^{* * *}\end{array}$ & $\begin{array}{l}4.076 \\
(70.35)^{* * *}\end{array}$ & $\begin{array}{l}4.226 \\
(88.64)^{* * *}\end{array}$ & $\begin{array}{l}4.256 \\
(81.62)^{* * *}\end{array}$ \\
\hline Urban & $\begin{array}{l}0.213 \\
(3.39)^{* * *}\end{array}$ & -- & $\begin{array}{l}0.103 \\
(1.91)^{*}\end{array}$ & --- \\
\hline Transportation & $\begin{array}{l}0.129 \\
(2.93)^{* * *}\end{array}$ & $\begin{array}{l}0.170 \\
(3.61)^{* * *}\end{array}$ & $\begin{array}{l}0.069 \\
(1.62)\end{array}$ & $\begin{array}{l}0.072 \\
(1.63)\end{array}$ \\
\hline Wheat & $\begin{array}{l}-0.128 \\
(-2.69)^{* *}\end{array}$ & $\begin{array}{l}-0.122 \\
(-2.41)^{* *}\end{array}$ & $\begin{array}{l}-0.083 \\
(-1.98)^{*}\end{array}$ & $\begin{array}{l}-0.105 \\
(-2.23)^{*}\end{array}$ \\
\hline Cotton & $\begin{array}{l}-0.027 \\
(-0.50)\end{array}$ & $\begin{array}{l}-0.037 \\
(-0.65)\end{array}$ & --- & --- \\
\hline Tobacco & $\begin{array}{l}0.085 \\
(1.64)\end{array}$ & $\begin{array}{l}0.076 \\
(1.40)\end{array}$ & --- & --- \\
\hline Animal Products & $\begin{array}{l}-0.013 \\
(-0.24)\end{array}$ & $\begin{array}{l}-0.044 \\
(-0.79)\end{array}$ & $\begin{array}{l}-0.042 \\
(-0.94)\end{array}$ & $\begin{array}{l}-0.061 \\
(-1.19)\end{array}$ \\
\hline Non-Specialized & $\begin{array}{l}-0.114 \\
(-1.79)\end{array}$ & $\begin{array}{l}-0.114 \\
(-1.71)\end{array}$ & $\begin{array}{l}-0.029 \\
(-0.61)\end{array}$ & $\begin{array}{l}-0.064 \\
(-1.22)\end{array}$ \\
\hline \multicolumn{5}{|l|}{$\begin{array}{l}\text { Dummies for manufacturing } \\
\text { groups }\end{array}$} \\
\hline Resource processing & $\begin{array}{l}-0.166 \\
(-4.14)^{* * *}\end{array}$ & $\begin{array}{l}-0.157 \\
(-3.73)^{* * *}\end{array}$ & $\begin{array}{l}-0.042 \\
(-0.93)\end{array}$ & $\begin{array}{l}-0.046 \\
(-0.95)\end{array}$ \\
\hline Iron \& metal products & $\begin{array}{l}0.133 \\
(1.59)\end{array}$ & $\begin{array}{l}0.129 \\
(1.43)\end{array}$ & $\begin{array}{l}-0.096 \\
(-1.32)\end{array}$ & $\begin{array}{l}-0.101 \\
(-1.31)\end{array}$ \\
\hline Leather \& leather goods & $\begin{array}{l}-0.029 \\
(-0.57)\end{array}$ & $\begin{array}{l}-0.009 \\
(-0.16)\end{array}$ & $\begin{array}{l}-0.077 \\
(-1.37)\end{array}$ & $\begin{array}{l}-0.089 \\
(-1.4)\end{array}$ \\
\hline Personal \& household goods & $\begin{array}{l}0.167 \\
(2.83)^{* * *}\end{array}$ & $\begin{array}{l}0.194 \\
(3.06)^{* * *}\end{array}$ & $\begin{array}{l}.0457 \\
(0.84)\end{array}$ & $\begin{array}{l}0.006 \\
(0.09)\end{array}$ \\
\hline$R^{2}$ & 0.08 & 0.06 & 0.03 & 0.02 \\
\hline$N$ & 1365 & 1235 & 938 & 760 \\
\hline
\end{tabular}

$*=$ Significant at the 5 percent level.

$* *=$ Significant at the 1 percent level.

$* * *=$ Significant at the .05 percent level. 


\section{Table 7, continued}

Notes and Sources: The urban variable is defined in Table 1. The dummy transportation variable represents counties that have both a town that was mentioned in the Population Census, and a railroad or a navigable waterway passing through or immediately adjacent to its borders. The information on the railroads and navigable waterways was obtained from Meyer et al, History of Transportation (1917). The variables representing agricultural products are also dummy variables representing whether or not a firm belongs to an agriculturally specialized county as described in Table 3. The intercept represents firms located in counties that were specialized in corn and categorized as miscellaneous. Figures in parentheses are $t$-statistics. The sample and the various adjustments are explained in Tables 2 and 3. 
of total factor productivity as the dependent variable are presented, with two estimated over southern manufacturing firms and two over firms in the East North Central. Of the two for each region, one was estimated over all firms within that region in the Bateman-Weiss sample, and the other was estimated over the firms in rural counties alone. Each of the regressions contained dummy variables to control for industry and access to low-cost transportation to extensive markets, and those estimated over a set of observations inclusive of urban firms included a dummy for being located in an urban county. The one consistent and statistically significant association between total factor productivity and local agricultural specialization is the finding that firms in wheat-specialized counties had lower total factor productivity than firms in corn-specialized counties (reflected in the intercept). Both the robustness and the plausible magnitudes of the coefficients on the dummmy variable for the manufacturing firm being located in a county specialized in wheat are reassuring. ${ }^{19}$ The peculiar result mentioned above of inconsistency across regions in the relative productivity of firms in nonspecialized counties or in counties specialized in animal products is absent here. In both regions, firms in such counties were estimated to have lower productivity than those in corn-specialized counties, but the differences seem small and are not statistically significant.

In Table 8, we check on the robustness of the finding of lower manufacturing productivity in wheat-specialized counties by varying the specification of the two regressions - one for each region -- estimated over both urban and rural firms. Instead of employing dummy variables for counties with different types of agricultural specialization, these regressions include continuous variables for the shares of total agricultural output accounted for by particular products. The qualitative results prove robust. Again, manufacturing firms 


\section{TABLE 8 \\ CROSS-SECTIONAL REGRESSION OF PRODUCTIVITY ON AGRICULTURAL SPECIALIZATION: SOUTH AND EAST NORTH CENTRAL, 1860}

\begin{tabular}{|c|c|c|}
\hline \multicolumn{3}{|c|}{ Dependent Variable: Log (Total Factor Productivity) } \\
\hline & South & ENC \\
\hline Intercept & $\begin{array}{l}4.037 \\
(107.76)^{* * *}\end{array}$ & $\begin{array}{l}4.301 \\
(70.59)^{* * *}\end{array}$ \\
\hline Urban & $\begin{array}{l}0.215 \\
(3.33)^{* * *}\end{array}$ & $\begin{array}{l}0.108 \\
(2.03)^{*} \\
\end{array}$ \\
\hline Transportation & $\begin{array}{l}0.121 \\
(2.74)^{* * *}\end{array}$ & $\begin{array}{l}0.067 \\
(1.58) \\
\end{array}$ \\
\hline$\%$ Wheat of Total Value $(\$)$ & $\begin{array}{l}-0.330 \\
(-2.00)^{*}\end{array}$ & $\begin{array}{l}-0.216 \\
(-2.15)^{*} \\
\end{array}$ \\
\hline$\%$ Cotton of Total Value $(\$)$ & $\begin{array}{l}-0.259 \\
(-1.37) \\
\end{array}$ & -- \\
\hline$\%$ Tobacco of Total Value $(\$)$ & $\begin{array}{l}0.371 \\
(2.00)^{*}\end{array}$ & -- \\
\hline$\%$ Animal Products of Total Value $(\$)$ & $\begin{array}{l}0.184 \\
(0.97) \\
\end{array}$ & $\begin{array}{l}-0.264 \\
(-1.59) \\
\end{array}$ \\
\hline \multicolumn{3}{|l|}{ Dummies for manufacturing groups } \\
\hline Resource processing & $\begin{array}{l}-0.169 \\
(-4.22)^{* * *}\end{array}$ & $\begin{array}{l}-0.039 \\
(-0.87) \\
\end{array}$ \\
\hline Iron \& metal products & $\begin{array}{l}0.147 \\
(1.75) \\
\end{array}$ & $\begin{array}{l}-0.100 \\
(-1.37) \\
\end{array}$ \\
\hline Leather \& leather goods & $\begin{array}{l}-0.020 \\
(-0.39) \\
\end{array}$ & $\begin{array}{l}-0.074 \\
(-1.32) \\
\end{array}$ \\
\hline Personal \& household goods & $\begin{array}{l}0.192 \\
(3.15)^{* * *}\end{array}$ & $\begin{array}{l}0.048 \\
(0.88) \\
\end{array}$ \\
\hline$R^{2}$ & 0.07 & 0.03 \\
\hline$N$ & 1365 & 938 \\
\hline
\end{tabular}

* = Significant at the 5 percent level.

** = Significant at the 1 percent level.

$* * *=$ Significant at the .05 percent level.

Notes and Sources: The main difference from Table 7 is that the variables representing agricultural specialization are continuous. The nature of agricultural specialization is discussed in the notes to Table 3. The intercept represents firms located in counties that were specialized in corn and categorized as miscellaneous. Figures in parentheses are $t$-statistics. See also the notes to Table 7. 
in counties with urban areas and with low cost-transportation to major centers had higher productivity, especially in the South. Moreover, and of greater relevance for our purposes, in both regions the productivity of firms declined significantly with the share of agricultural output composed of wheat. ${ }^{20}$ Not only was the magnitude of this effect substantial, but its statistical significance was robust to changes in the mix of crop share variables included in the specification. The only other statistically significant relationship we found between manufacturing productivity and agricultural composition was the positive association with tobacco reported for the South.

These patterns of variation in manufacturing productivity across agricultural areas yield some interesting implications for our understanding of manufacturing development in the South, and of the relationship between local agriculture and manufacturing more generally. They indicate, first of all, that although counties that were relatively specialized in cotton had much less manufacturing output per capita than other areas of the South, the productivity of the manufacturing firms that were operating in those localities was not at all deficient. ${ }^{21}$ This finding, coupled with the lower productivity and yet high manufacturing output per capita in wheat-specialized areas, supports the position that the South had relatively little manufacturing, compared to the East North Central, because it was not economical to commit resources to such activity in the parts of the region with a strong comparative advantage in cotton. Conversely, the lower manufacturing productivity in counties specialized in wheat production (evident in both regions), together with the relatively high levels of manufacturing output per capita in those same counties, suggests that even in the wheat belt, manufacturing had the character of a seasonal sideline activity.

Much of the manufacturing in rural areas consisted of the processing of agricultural 
products (like leather, lumber, and flour), and production in general took place where and during those parts of the year in which the opportunity cost of resources in agriculture was lower. In districts that were relatively specialized in crops with highly seasonal labor requirements, like wheat, there were ample supplies of labor for manufacturing carried out during the offpeak periods. However, relying on seasonal labor supplies meant that firms would tend to use organizations and techniques that were more flexible or adaptable to interruptions in operations, rather than opt for those that would be technically efficient in a context in which operations would be full-time year-round. ${ }^{22}$ Such enterprises survived in competition because they were conducive to harnessing labor with low opportunity costs. In contrast, there might have been less overall manufacturing in agricultural areas lacking such supplies of cheap labor, but firms that did operate in such environments were more likely to operate full-time and use the best practice technologies. In this view, it was not coincidental that in both regions manufacturing per capita was highest in counties specialized in wheat (where labor requirements were extremely seasonal) and animal products (where a high fraction of agricultural output was raw materials for manufacturing), and lowest in counties specialized in cotton (where there was an especially strong comparative advantage in agriculture and where there was less seasonality in labor requirements). ${ }^{23}$

\section{III}

The empirical analysis of the manufacturing firm data, linked to information on the composition of local agricultural output, has yielded two very interesting results. The first is the finding that southern counties which were specialized in wheat, tobacco, animal products, and corn were quite comparable to rural areas in the East North Central with 
respect to the levels of manufacturing value added per capita. The districts of the South with markedly little manufacturing activity were those that were either specialized in, or had substantial shares of resources devoted to, cotton production. These patterns raise questions about the reasons for the relatively limited manufacturing development in the South. Many scholars have claimed a direct role for slavery in accounting for the disparity, but this evidence suggests that the explanation may be more complex. In particular, there should perhaps be more study of the idea that the South's exploitation of the comparative advantage of certain of its areas in cotton production was responsible for the less than impressive region-wide performance. The one caveat to this implication, however, is that our analysis has been confined to examining the effects of local agriculture on local manufacturing. It might be argued that a higher level of aggregation would be more appropriate for examining the linkages between slavery, cotton production, and the development of the manufacturing sector.

The second finding of great interest is the economically and statistically significant finding of lower manufacturing productivity in rural counties that were specialized in wheat production. This result is relevant to recent work suggesting that manufacturing firms located in areas with highly seasonal agricultural demands for labor might not have operated full-time year round. ${ }^{24}$ The lower productivity of firms located in counties producing wheat, the major agricultural output with extreme seasonality in labor requirements, is certainly consistent with such an argument. Lower measured productivity could stem from either a form of manufacturing organization that was less efficient technically but selected because its greater flexibility was well suited for contexts in which the opportunity cost of labor was extremely variable, or from the way in which data on manufacturing firm operations was 
recorded. If the annual output of a firm operating part-time or seasonally, was reported together with the number of workers employed when the firm was in operation, estimates of the total factor productivity of such firms would be downward biased. Regardless of which of these two sources of the computed lower productivity is more significant, the implication that such seasonality in manufacturing firm operations was more prevalent in areas specialized in wheat production is important.

\section{ENDNOTES}

1. See, for example, Mendels (1972); Thirsk (1961); Snell (1985); and Gullickson (1983).

2. See, for example, Parker (1970); Wright (1986); and Weiman (1990).

3. For a variety of hypotheses concerning the sources of the limited industrial development of the South, see Fogel (1989); Genovese (1965); Earle and Hoffman (1980); Weiman (1988); Siegel (1987); Bateman and Weiss 1975, 1976, and 1981); Goldin and Sokoloff (1982 and 1984).

4. Sokoloff and Dollar (1997). The relationship between the agricultural sector and the course of industrial development has also been discussed by scholars concerned with why early American industrialization was initially concentrated in New England. See, for example, Field (1978).

5. Bateman and Weiss (1981); Meyer (1988); Fogel (1989); and Tchakerian (1994).

6. See Bateman and Weiss (1981) for a discussion of the data set.

7. The sources of this divergence in the industrial development of the North and South have been much debated. For a sampling of different views, see Fogel and Engerman (1974); Wright (1978 and 1986); and Fogel (1989). Because we were concerned with explanations that turn on differences in agricultural conditions, we focused our empirical work on manufacturing in rural areas, and followed the rather conventional path of comparing the South to the East North Central states, instead of to the entire North. The logic for this particular comparison is that it contrasts two regions which were primarily agricultural and just beginning to industrialize at 1860 . An alternative approach, however, one which would highlight other questions about regional divergence, might compare areas that were settled at about the same time period. 
8. See the discussion in Fogel (1989), chpt. 4.

\section{Also see Sokoloff (1984).}

10. With the approach we adopted, some counties satisfied the criterion to be classified as specialized in more than one product. Other methods of categorizing counties by specialization were examined as well, such as employing product per capita as the standard, but the basic qualitative results reported in this paper were robust to them.

11. The finding that counties specialized in cotton production had much lower levels of manufacturing output per capita was robust to every method of classifying counties by specialization we examined. In general, the only qualitative result that was somewhat sensitive to the classification method was the relative amounts of manufactures in nonspecialized southern counties. More specifically, some methods lead to a set of counties classified as nonspecialized that had crop mixes and levels of manufactures per capita more like those counties that were not specialized in cotton.

12. The very low level of manufacturing output per capita in cotton-specialized counties would not be very significant, except that over a quarter of the South's population resided in these counties. The total proportion of the population that was located in areas which were quite focused on cotton was even higher, since there were many other counties with high cotton shares that did not meet our top quartile criterion for being classified as specialized in cotton production. The percentages sum to more than 100 , because counties could satisfy the criterion for specialization in more than one crop, but 25.8 percent of the South's population was in counties specialized in cotton, 17.5 percent for those specialized in wheat, 13.5 percent for those in corn, 18.3 percent for those in tobacco, 14.9 percent for those in animal products, and 8.7 percent for those counties categorized as nonspecialized. In the East North Central, 30.3 percent of the population was in counties specialized in wheat, 24.0 percent for those in corn, 28.8 percent in animal products, and 33.2 percent of the population was in counties classified as nonspecialized.

13. This assessment is based on a simple counterfactual calculation, employing the figures reported in Tables 1 and 3, where manufacturing value added per capita for urban counties in the South was raised to the level prevailing in urban counties of the East North Central. Although one can carry out the decomposition in several different ways, and increase the significance of what was going on in cities by taking account of the different fractions of the regional populations in urban areas, the qualitative result about the importance of the limited amount of manufacturing in areas with a focus on cotton production is robust.

14. The point estimates from the regressions of manufacturing output per capita are uniformly lower than those estimated from the firm data. This is probably due to the larger firms being more likely to have had complete information recorded in the manuscripts, and thus to appear in the Bateman-Weiss sample. Hence, these figures suggest a lesser role for the manufacturing shortfall in cotton-specialized counties in explaining the gap

between the South and the Midwest. Given that the disproportionate underenumeration or 
imperfect enumeration of smaller firms was probably characteristic of both the Midwest and the South, it is especially difficult to attach a precise number to the share of the regional gap that was accounted for by the cotton belt. It appears to have been quite substantial however.

15. As might be inferred from Gallman (1970) and Fogel and Engerman (1980), the extraordinarily high shares of output accounted for by cotton in the so-called cottonspecialized counties were not due to minuscule outputs of other products. There were, on average, respectable levels of some other agricultural products on an absolute per capita basis in these counties. The high cotton shares were primarily attributable to the remarkably large amounts of cotton produced in addition to the other outputs. It would be useful to be able to compare the rates of return on investment in manufacturing, on cotton production, and on agriculture in general -- in both the South and the East North Central. Bateman and Weiss (1981) recognized this, and constructed estimates of the respective rates of return. Unfortunately, the qualitative results of the comparisons are not robust to how one handles a variety of tricky issues, such as how to value the entrepreneurial labor input. Hence, it would be quite difficult to determine on the basis of such estimates, whether there was overinvestment in cotton production (or in agriculture generally) and under-investment in manufacturing in either or both of the two regions.

16. Although scholars may differ on why, there is general agreement that slavery in some way contributed to the overall southern comparative advantage in cotton production. Many believe that the institution of slavery raised productivity in cotton production, and accept the evidence of Fogel and Engerman (1980) that the use of slaves on large-scale plantations, as opposed to free labor, was associated with higher total factor productivity in the production of cotton, but not in the production of other crops of quantitative importance. Others might dispute that evidence, but would concur that the availability of slave labor encouraged cotton production, if only because large-scale producers were less risk averse and more inclined toward employing workers to produce cotton. For example, see Wright (1979). Still others (see Wade (1964)) would contend that slavery made for a competitive advantage in agriculture, if not in cotton specifically, because slaves were not competitive with free workers in manufacturing. Although adherents to these perspectives would all agree that the comparative advantage of southern counties specialized in cotton production was enhanced by the existence of slavery, and that slaves were disproportionately concentrated in those districts, they would also be in accord that differences in soil type and climate accounted for substantial geographic variation across the South in terms of environmental suitability for the cultivation of cotton. This relative suitability for cotton cultivation was not constant over time, but it was nevertheless rather stable over the second half of the nineteenth century. Moreover, given that virtually all areas of the South had substantial proportions of the population composed of slaves, and that counties other than those classified as specialized in cotton or as nonspecialized had levels of manufacturing output per capita comparable to those with similar crop mixes in the East North Central, one cannot dismiss the very low manufacturing activity in cotton-specialized counties as due merely to the large number of slaves there. Indeed, Table 4 provides strong evidence on this point. 
17. For discussions of the international comparative advantage of the U.S. South, see Wright (1978) and Fogel (1989).

18. The difference in manufacturing productivity between nonspecialized counties and counties specialized in cotton is interesting since, as noted above, the former also had quite high cotton shares. Lower productivity in nonspecialized counties might, accordingly, have been due to many of them being located in "upland" areas rather distant from general markets. The isolation from general markets might be expected to have led to low household incomes, low demand for manufactures, and limited competition as well as underemployment in manufacturing production.

19. Two other features of the regression results should be noted. First, no direct measures of firm size were included as independent variables, because of our sense (confirmed by the data) that smaller, less efficient firms were more likely to be located in counties specialized in wheat production. The logic is that manufacturing was more likely to be interrupted by seasonal variation in the opportunity cost of labor in those districts, relative to others, and that manufacturing enterprises there would accordingly have been smaller so as to maintain greater flexibility in operations and reduce the cost of idling fixed capital. Smaller establishments would be better able to attain these goals, because coordinating the activity of one or two workers is easier than coordinating the activity of three or more, and the small size allows manufacturers to save on fixed capital by operating out of their houses. When the same regressions were estimated with dummies for firm size, however, the explanatory power of the regressions increased (as reflected in $R^{2} s$ ) and the qualitative results held. That is, both the absolute value and the statistical signficance of the coefficient on the dummy for location in a wheat-specialized county decreased. The coefficient remained negative and statistically signficant, however, over establishments in the South, and negative and marginally significant in the East North Central. These slight changes in response to the inclusion of the size dummies is consistent with our view of the underlying patterns in the data and the structure of what was going on. The other feature to note is that the low $\mathrm{R}^{2} \mathrm{~s}$ are due both to the absence of dummies for size, and to the use of total factor productivity as the dependent variable, rather than using output as the dependent variable with the inputs appearing as additional independent variables. Again, the qualitative result concerning the wheat dummy is robust to this choice between alternative specifications. The proportion of rural manufacturing firm observations used in our analysis with more than five employees is just over (under) 20 percent in the South (East North Central).

20. Again, these results are robust to different methods of classifiying counties by product specialization.

21. One possible source of the low level of manufacturing output in these counties is that manufacturing activity on large slave planatations, which were disproportionately located there, may have been undercounted. Although it is likely that there was some underenumeration of this sort, on plantations and elsewhere, we are doubtful that this problem could account for the qualitative pattern. Not only was the discrepancy in manufacturing output per capita between counties specialized in cotton and other parts of the South substantial, but large planations and counties specialized in cotton already appear 
highly productive on the basis of enumerated outputs. Another argument for why there was not more manufacturing in counties with extensive cotton production might be that cotton (as opposed to grains or animal products) did not require much in the way of processing, and that it was a relatively cheap raw material to transport elsewhere for use as an input into manufacturing or for consumption as a final product.

22. For more evidence on these points from pre- and early-industrial France, England, and the United States, as well as elaboration of these arguments, see Postel-Vinay (1994); Magnac and Postel-Vinay (1997); and Sokoloff and Dollar (1997).

23. For a discussion of the limited seasonality in labor requirements on farms cultivating cotton, see Fogel (1989), pp. 161-162, and for evidence on labor requirements for a variety of agricultural products, see Covert (1912); and Free (1938). The basic source of the extreme seasonality in labor requirements for the production of wheat is the very narrow window of time in which the crop must be harvested. Beyond this window, the quality and quantity of the harvest drops off rapidly. This contrasts sharply with corn, whose harvest can be stretched out over a rather long period without much deterioration of the crop. For discussion of nineteenth-century seasonality in U.S. labor markets and its relationship to agriculture generally, see Engerman and Goldin (1994). For evidence about the pronounced seasonality associated with wheat production, and its impact on manufacturing activity in early industrial economies, see Postel-Vinay (1994); and Sokoloff and Dollar (1997). Although Sokoloff and Dollar emphasize how well suited the cottage organization of manufacturing was to settings with great variability in the opportunity cost of labor, they agree with Postel-Vinay that all classes of establishments might have had their operations disrupted if the seasonality in labor markets were substantial enough. For discussion of the seasonal mobility of labor between agricultural and non-agricultural employments in the Midwest during the period under study, see Schob (1975).

24. Postel-Vinay (1994); Postel-Vinay (1997); and Sokoloff and Dollar (1997). 


\section{REFERENCES}

Bateman, Fred, and Weiss, Thomas (1975), "Comparative Regional Development in Antebellum Manufacturing." Journal of Economic History 35(1),182-208.

Bateman, Fred, and Weiss, Thomas (1976), "Manufacturing in the Antebellum South." Research in Economic History 1,1-44.

Bateman, Fred, and Weiss, Thomas (1981), A Deplorable Scarcity. Chapel Hill: University of North Carolina Press.

Covert, James (1912), Seedtime and Harvest: Cereals. Flax, Cotton and Tobacco: Dates of Planting and Harvesting East of Meridians 102-104 in the United States, U.S. Department of Agriculture, Bureau of Statistics Bulletin 85. Washington, D.C.: Government Printing Office.

Earle, Carville and Ronald Hoffman (1980), "The Foundation of the Modern Economy: Agriculture and the Costs of Labor in the United States and England, 1800-60,"American Historical Review 85(4), 1055-1094.

Engerman, Stanley, and Goldin, Claudia (1994), "Seasonality in Nineteenth-Century Labor Markets." In Thomas Weiss and Donald Schaefer (Eds.), American Economic Development in Historical Perspective. Stanford: Stanford University Press.

Field, Alexander J. (1978), "Sectoral Shifts in Antebellum Massachusetts: A Reconsideration." Explorations in Economic History 15(2),146-171.

Fogel, Robert W. (1989), Without Consent or Contract: The Rise and Fall of American Slavery. New York: W.W. Norton.

Fogel, Robert W., and Engerman, Stanley L. (1974), Time on the Cross. Boston: Little, Brown. 
Fogel Robert W., and Engerman, Stanley L. (1980), "Explaining the Relative Efficiency of Slave Agriculture in the Antebellum South: Reply." American Economic Review $70(3), 672-690$.

Free, Benjamin J. (1938), Seasonal Employment in Agriculture, Works Progress Administration. Washington, D.C.: Government Printing Office.

Gallman, Robert E. (1970), "Self-Sufficiency of the Cotton Economy of the Antebellum South." In William Parker (Ed.), The Structure of the Cotton Economy of the Antebellum South. Washington, D.C.: Agricultural History Society. Pp. 5-24.

Genovese, Eugene (1965), The Political Economy of Slavery. New York: Pantheon.

Goldin, Claudia, and Sokoloff, Kenneth (1982), "Women, Children, and Industrialization in the Early Republic: Evidence from the Manufacturing Censuses." Journal of Economic History 42(4), 741-74.

Goldin, Claudia, and Sokoloff, Kenneth (1984), "The Relative Productivity Hypothesis of Industrialization: The American Case, 1820 to 1850." Quarterly Journal of Economics $99(3), 461-87$.

Gullickson, Gay L. (1983), "Agriculture and Cottage Industry: Redefining the Causes of Proto-industrialization." Joumal of Economic History 43(4),831-850.

Magnac, Thierry, and Postel-Vinay, Gilles (1997), "Wage Competition Between Agriculture and Industry in Mid-Nineteenth Century France." Explorations in Economic History $34(1), 1-26$.

Mendels, Franklin F. (1972), "Protoindustrialization: The First Phase of the Industrialization Process." Journal of Economic History 32(2), 241-61.

Meyer, David R. (1988), "The Industrial Retardation of Southern Cities, 1860-1880." Explorations in Economic History 25(4),366-86. 
Parker, William N. (1970), "Slavery and Southern Economic Development: An Hypothesis and Some Evidence." Agricultural History 44(1),115-25.

Postel-Vinay, Gilles (1994), "The Disintegration of Traditional Labor Markets in France: From Agriculture and Industry to Agriculture or Industry." In George Grantham and Mary McKinnon (Eds.), Labor Market Evolution. London: Routledge.

Schob, David (1975), Hired Hands and Plowboys: Farm Labor in the Midwest, 1815-60.

Urbana: University of Illinois Press.

Siegel, Frederick F. (1987), The Roots of Southern Distinctiveness: Tobacco and Society in Danville. Virginia, 1780-1865. Chapel Hill: University of North Carolina Press.

Snell, K.D.M. (1985), Annals of the Labouring Poor. Cambridge: Cambridge University Press.

Sokoloff, Kenneth L. (1984), "Was the Transition from the Artisanal Shop to the Nonmechanized Factory Associated With Gains in Efficiency?: Evidence from the U.S. Manufacturing Censuses of 1820 and 1850," Explorations in Economic History 21(4),351382.

Sokoloff, Kenneth L., and Dollar, David (1997), "Agricultural Seasonality and the Organization of Manufacturing in Early Industrial Societies: The Contrast Between England and the United States." Journal of Economic History 57(2), forthcoming. Tchakerian, Viken (1994), "Productivity, Extent of Markets, and Manufacturing in the Late Antebellum South and Midwest." Journal of Economic History 54(3),497-525. Thirsk, Joan (1961), "Industries in the Countryside." In F.J. Fisher (ed), Essays in the Economic and Social History of Tudor and Stuart England. Cambridge: Cambridge University Press.

Wade, Richard C. (1964), Slavery in the Cities: The South 1820-1860. New York: Oxford 
University Press.

Weiman, David (1988), "Urban Growth on the Periphery of the Antebellum Cotton Belt: Atlanta, 1847-1860. "Journal of Economic History 48(2),259-72.

Weiman, David (1990), "Staple Crops and Slave Plantations: Alternative Perspectives on Regional Development in the Antebellum Cotton South." In Lou Ferleger (ed.), Agriculture and National Development. Ames, IA: Iowa State University Press.

Wright, Gavin (1978), The Political Economy of the Cotton South. New York: W.W. Norton. Wright, Gavin (1986), Old South, New South: Revolutions in the Southern Economy Since the Civil War. New York: Basic Books. 